\title{
ЖИЗНЕСПОСОБНОСТЬ И ВИРУЛЕНТНОСТЬ ИЗОЛЯТОВ ВОЗБУДИТЕЛЯ БУРОЙ РЖАВЧИНЫ ПШЕНИЦЫ (Puccinia triticina Eriks.) ПРИ ДОЛГОСРОЧНОМ ХРАНЕНИИ
}

\author{
Н.С. ЖЕМЧУЖИНА, М.И. КИСЕЛЕВА, А.И. ЖЕМЧУЖИНА, \\ С.А. ЕЛИЗАРОВА
}

В Государственной коллекции фитопатогенных микроорганизмов Всероссийского НИИ фитопатологии (ФГБНУ ВНИИФ) накоплено огромное количество изолятов возбудителя бурой ржавчины (Puccinia triticina Eriks.) - крайне вредоносного и эпифитотийного заболевания пшеницы. Ежегодно коллекция пополняется новыми изолятами гриба, проявляющими значительное разнообразие по составу генов вирулентности и происхождению. Одна из основных задач коллекции - сохранение изолятов гриба без потери их биологических свойств для проведения лабораторных и полевых экспериментов. В настоящей работе впервые установлена корреляционная зависимость между жизнеспособностью изолятов бурой ржавчины и длительностью хранения в условиях низких положительных и ультранизких температур. Целью наших 10-летних исследований была сравнительная оценка жизнеспособности и вирулентности коллекционных изолятов Puccinia triticina после длительного хранении при $+4{ }^{\circ} \mathrm{C}$ и -80 $\mathrm{C}$. Материалом служили 124 изолята P. triticina, выделенные с пораженных образцов пшеницы (Triticum aestivum L.) в 2005, 2006, 2008, 2009, 2010 и 2012 годах в Центральном, Северо-Кавказском и Западно-Сибирском регионах Российской Федерации. Растения восприимчивой линии Хакасская и линий пшеницы с единичными генами устойчивости выращивали по стандартной методике в гидропонной культуре. Гены вирулентности в изолятах $\boldsymbol{P}$. triticina определяли на наборах $L \boldsymbol{r}$-линий сорта Thatcher с генами ювенильной устойчивости. В бытовом холодильнике споры гриба хранили при температуре $+4{ }^{\circ} \mathrm{C}$ в течение 1-10 мес в пробирках; в морозильной камере REVCO («Revco», CША) - при $-80{ }^{\circ} \mathrm{C}$ в течение $3,4,5,6,7$ и 10 лет в пластиковых контейнерах. Изоляты грибы различались по вирулентности и были отнесены к 74 фенотипам. Жизнеспособность снятых с хранения изолятов определяли двумя способами: по прорастанию спор, нанесенных на пластинки с 2 \% голодным агар-агаром, и инокуляцией суспензией спор всходов пшеницы восприимчивого сорта. Хранение уредоспор возбудителя бурой ржавчины в условиях низких положительных температур быстро приводило к ослаблению жизнеспособности гриба, вплоть до полной гибели. В течение 12 мес изоляты сохраняли высокий процент прорастания спор (от 48 до $95 \%$ ), а через 6 мес этот показатель снижался до 3,0-22,7 \%. Коэффициент корреляция между числом проросших спор на $2 \%$ голодном агаре и длительностью хранения при низкой положительной температуре составляла 0,79. В условиях низких отрицательных температур изоляты гриба оставались жизнеспособными при хранении в течение 3-10 лет. Число проросших спор у разных изолятов, независимо от срока хранения, составляло 25-79 \%, а интенсивность поражения растений достигала 25-100 \%. На показатели жизнеспособности изолятов при одинаковых сроках хранения влияли многие факторы. Основными из них могли быть погрешности при подготовке материала перед закладкой на хранение, при выведении из анабиотического состояния или нарушения режима хранения технического характера. Тем не менее хранение коллекционных образцов $P$. triticina при низких отрицательных температурах обеспечило достаточно высокую выживаемость в течение 10 лет. После хранения в течение 7 лет проверка вирулентности изолятов гриба для растений пшеницы с использованием линий-дифференциаторов с генами $\operatorname{Lr} 9$ и $\operatorname{Lr} 19$ показала идентичность реакций до и после проведения опыта. Таким образом, хранение спорового материала $P$. triticina в морозильных камерах при температуре $-80{ }^{\circ} \mathrm{C}$ позволяет максимально сохранить его без изменения жизнеспособности и вирулентности.

Ключевые слова: коллекция микроорганизмов, бурая ржавчина, изолят, популяция, вирулентность, хранение.

Государственная коллекция фитопатогенных микроорганизмов Всероссийского НИИ фитопатологии (ФГБНУ ВНИИФ) предназначена для длительного хранения в жизнеспособном состоянии возбудителей болезней сельскохозяйственных культур (1-3). В фонде Коллекции находятся около 5500 штаммов возбудителей болезней растений, вызываемых грибами, бактериями и вирусами. За последние 10 лет в коллекцию собрано более 1000 изолятов Puccinia triticina Eriks. из разных районов возделыва- 
ния пшеницы в России. Спектр вирулентности коллекционных образцов гриба позволяет сохранить разнообразие природных популяций $P$. triticina, использовать их для прогноза динамики частоты встречаемости генов устойчивости и для селекционных испытаний пшеницы $(4,5)$.

Система мониторинга вирулентности популяций P. triticina позволяет выявлять новые гены устойчивости к патогену. В природе на формирование вирулентности популяций гриба значительное влияние оказывает мутационная изменчивость и рекомбинация генетического материала, а также миграция спор (6-8). Вследствие сопряженной эволюции в системе хозяин-патоген на устойчивых сортах пшеницы идет постоянный отбор вирулентных клонов бурой ржавчины. Вирулентные клоны гриба накапливаются в популяциях P. triticina, авирулентные вытесняются и с течением времени либо элиминируют, либо сохраняются в незначительном количестве. На ежегодные колебания частоты встречаемости рас бурой ржавчины влияют погодные условия и состав возделываемых сортов пшеницы $(5,9)$. Ежегодный отбор изолятов P. triticina в коллекцию дает возможность сравнить генетический материал разных лет и таким образом проследить изменения, происходящие в популяциях гриба по частоте генов вирулентности, а также определить роль возделываемых сортов пшеницы на появление и распространение рас патогена $(10,11)$. В результате мониторинга вирулентности популяций P. triticina отслеживаются новые потенциально опасные расы гриба. На основании изучения динамики и частоты встречаемости генов вирулентности определяется степень эффективности Lr-генов пшеницы в регионах России, устанавливается перспективность их включения в селекционный процесс. Информация о генофонде популяций патогена позволяет использовать необходимый материал для создания искусственных инфекционных фонов, а также для оценки генотипа устойчивости сортов пшеницы к возбудителю бурой ржавчины $(12,13)$.

Основным фактором, влияющим на появление новых рас P. triticina и на изменение их частоты встречаемости, служит естественный отбор, который происходит в популяциях гриба под влиянием сортов с расоспецифической устойчивостью (14). В связи с этим информация о выявлении клонов возбудителя бурой ржавчины пшеницы, преодолевающих устойчивость сортов-хозяев с эффективными генами устойчивости, становится актуальной для отбора образцов, которые могут использоваться в селекции на иммунитет к болезни.

Известно, что более 90 \% микроорганизмов, в том числе и ржавчинные грибы, невозможно культивировать на искусственной среде. Гриб P. triticina - экономически важный объект, хранение изолятов которого часто вызывает определенные затруднения. Исследования, связанные с необходимостью сохранения таких микроорганизмов, предполагают выбор условий консервации и реактивации, при которых возможно восстановление жизнеспособности патогена. Поддержание изолятов гриба в рабочем состоянии и сохранение их ценных свойств считаются важными и приоритетными условиями для практического использования (15-17).

Перед создателями коллекции стояла задача не только сохранения изолятов P. triticina в жизнеспособном состоянии, но и оптимизации условий для поддержания физиологических свойств гриба $(18,19)$. Известно, что традиционные методы хранения ржавчинных грибов (высушивание и запаивание уредоспор в ампулы) не гарантируют поддержания высокой жизнеспособности материала в течение длительного времени.

Хранение в жидком азоте требует значительных материальных и 
трудовых затрат. Хранение спор ржавчины в бытовых холодильниках при низких положительных температурах позволяет им оставаться жизнеспособными в течение нескольких месяцев, а в виде гербарного материала до года. В текущей повседневной работе, которая состоит из непрерывно повторяющихся циклов, требующих краткосрочного поддержания гриба в жизнеспособном состоянии, хранение спор при низких положительных температурах оправдано. Однако длительное хранение гриба требует других условий.

Один из распространенных современных методов консервации биоматериала без изменения его жизнеспособности - хранение в морозильниках с ультранизкими температурами $(20,21)$. Для многих микологических объектов рекомендован способ размещения в морозильных камерах при температуре $-80{ }^{\circ} \mathrm{C}$. Низкие отрицательные температуры вызывают остановку биохимических процессов в клетках, в том числе обмена веществ. Использование морозильников с ультранизкими температурами обеспечивает сохранность спорового материала ржавчинных грибов без изменения биологических свойств в течение 7 лет и более (22-24).

В настоящей работе впервые установлена корреляционная зависимость между жизнеспособностью изолятов бурой ржавчины и длительностью хранения в условиях низких положительных и ультранизких температур. С увеличением срока хранения спор при низкой положительной температуре жизнеспособность изолятов гриба падала, что выражалось в редукции прорастания спор на $2 \%$ голодном агар-агаре и снижении интенсивности поражения всходов пшеницы. В условиях ультранизких температур, независимо от срока хранения, изоляты гриба сохраняли способность к прорастанию на голодном агаре и заражению растений. Длительность хранения в условиях ультранизких температур не оказывала влияния на изменение признака вирулентности.

Целью наших исследований была сравнительная оценка жизнеспособности и вирулентности коллекционных изолятов Puccinia triticina при длительном хранении в условиях низкой положительной $\left(+4{ }^{\circ} \mathrm{C}\right)$ и низкой отрицательной температур $\left(-80^{\circ} \mathrm{C}\right)$.

Методика. Материалом для 10-летнего исследования послужили 124 изолята P. triticina, выделенные с пораженных образцов пшеницы (Triticum aestivum L.) в 2005, 2006, 2008, 2009, 2010 и 2012 годах в Центральном, Северо-Кавказском и Западно-Сибирском регионах Российской Федерации.

Выделение, размножение и идентификацию монопустульных изолятов P. triticina по вирулентности проводили при оптимальных условиях для развития растений и патогена: относительная среднесуточная температура воздуха $+20{ }^{\circ} \mathrm{C}$, относительная влажность воздуха - $60 \%$ днем и 70 \% ночью, освещенность - 10-15 тыс. лк, фотопериод - 16 ч.

Растения восприимчивой линии Хакасская и линий пшеницы с единичными генами устойчивости выращивали по стандартной методике в гидропонной культуре (12). Гены вирулентности в изолятах P. triticina определяли на наборах $L r$-линий сорта Thatcher с генами ювенильной устойчивости. Набор с генами ювенильной устойчивости включал $42 \mathrm{Lr}$ линии: Lr1, Lr2a, Lr2b, Lr2c, Lr3a, Lr3bg, Lr3ka, Lr9, Lr10, Lr11, Lr14a, Lr14b, Lr15, Lr16, Lr17, Lr18, Lr19, Lr20, Lr21, Lr23, Lr24, Lr25, Lr26, Lr27+Lr31, Lr28, Lr29, Lr30, Lr32, Lr33, Lr36, Lr38, Lr39, Lr40, Lr 41, Lr 42, Lr44, Lr45, Lr46, Lr47, Lr51, Lr53, LrB (25).

Растения (25 шт.) в фазу 5-6-суточных всходов инокулировали посредством нанесения водной суспензии уредоспор на нижнюю сторону 
листовой пластинки. Навеску спор возбудителя бурой ржавчины готовили из расчета 0,5 мг спор/мл воды. Для лучшего смачивания спор в воду добавляли одну-две капли $\mathrm{Tween}^{\mathrm{R}} 20$. Споры наносили на растения с помощью скальпеля, предварительно снимая пальцами восковой налет с листьев. Зараженные растения пшеницы помещали во влажную камеру при температуре +18-20 ${ }^{\circ} \mathrm{C}$ на 16-20 ч, а затем - в камеру искусственного климата с контролируемыми условиями температуры, влажности и освещения. Через 5-7 сут после инокуляции осматривали растения и отмечали появление на них признаков болезни, которое оценивали по общепринятым в международной практике методикам (26-28). После дифференциации по вирулентности каждый изолят P. triticina размножали на восприимчивой линии Хакасская до накопления 4-5 мг биомассы и помещали на хранение в Государственную коллекцию ФГБНУ ВНИИФ.

В бытовом холодильнике споры гриба хранили при $+4{ }^{\circ} \mathrm{C}$ в течение 1-10 мес в пробирках; в морозильной камере REVCO («Revco», CША) при $-80{ }^{\circ} \mathrm{C}$ в течение $3,4,5,6,7$ и 10 лет в пластиковых контейнерах. Перед каждой проверкой состояния материала уредоспоры возбудителя бурой ржавчины, хранившиеся в морозильных камерах, выводили из состояния анабиоза, применяя термическую обработку спорового материала при $+45^{\circ} \mathrm{C}$ в течение 5 мин (29).

Жизнеспособность изолятов определяли двумя способами: по прорастанию спор, нанесенных на пластинки с $2 \%$ голодным агар-агаром, и инокуляцией суспензией спор всходов пшеницы восприимчивого сорта (30). В первом случае на предметные стекла, разложенные в стерильные чашки Петри, разливали расплавленный $2 \%$ голодный агар-агар. Споры наносили на агаровую пластинку с помощью препаровальной иглы. Равномерность рассева достигалась легким постукиванием иглы по краю чашки Петри. Затем чашки закрывали и оставляли при комнатной температуре. Через 6 ч стекла просматривали под микроскопом при большом увеличении и подсчитывали число проросших спор из 100 просмотренных (трехкратная повторность). Жизнеспособность спор каждого изолята выражали в процентах. Для проверки способности заражать 5-6-суточные всходы пшеницы универсально восприимчивой линии Хакасская растения инокулировали спорами гриба, снятыми с хранения и выведенными из анабиоза. Показателем жизнеспособности спор служило образование пустул на поверхности листьев растений.

При статистической обработке результатов рассчитывали коэффициенты корреляции (r) и коэффициенты ковариации (covariance), используя программу Microsoft Excel $(2,3)$.

Результаты. Все использованные в работе изоляты P. triticina были промаркированы по происхождению и вирулентности. Дифференциация изолятов P. triticina по их реакции на линиях пшеницы с генами ювенильной устойчивости выявила значительные различия по вирулентности. Изоляты гриба содержали разное число генов вирулентности и были отнесены к 74 фенотипам. Хотя изоляты выделяли из популяций P. triticina в разные годы, для всех них было характерно наличие одних и тех же 12 генов вирулентности: $p 3 a, p 3 b g, p 3 k a, p 10, p 14 a, p 14 b, p 17, p 18, p 21, p 30, p 33$, $p B$. Изоляты $P$. triticina различались между собой по наличию генов $p 1$, $p 2 a, p 2 b, p 2 c, p 9, p 11, p 15, p 16, p 19, p 20, p 23, p 25, p 26, p 27+p 31, p 28, p 32$, $p 36, p 38, p 39, p 40, p 44, p 46$. Ни в одном из коллекционных изолятов гриба не были выявлены гены $p 24, p 29, p 41, p 42, p 45, p 47, p 51, p 53$.

При хранении уредоспор возбудителя бурой ржавчины в условиях низких положительных температур наступало быстрое ослабление жизне- 
способности гриба (табл. 1). Так, после хранения при $+4{ }^{\circ} \mathrm{C}$ в течение $1-2$ мес изоляты имели высокую (от 48 до $95 \%$ ) всхожесть спор, а через 6 мес этот показатель снижался до 3,0-22,7 \%. После 10 мес хранения споры оказались полностью невсхожими. Корреляция между числом проросших спор на $2 \%$ голодном агар-агаре и длительностью хранения в бытовом холодильнике составляла 0,79. Аналогичные результаты получили и при заражении всходов восприимчивого сорта Хакасская споровыми суспензиями: с увеличением срока хранения спор интенсивность поражения всходов пшеницы снижалась.

1. Жизнеспособность уредоспор Puccinia triticina Eriks. на $2 \%$ голодном агаре и всходах пшеницы восприимчивого сорта Хакасская после хранения в течение 1-10 мес при температуре $+4{ }^{\circ} \mathrm{C}$

\begin{tabular}{l|c|c|c}
\hline $\begin{array}{l}\text { Продолжительность } \\
\text { хранения, мес }\end{array}$ & Число изолятов & $\begin{array}{c}\text { Число проросших } \\
\text { спор (min-max), \% }\end{array}$ & $\begin{array}{c}\text { Интенсивность поражения всхо- } \\
\text { дов пшеницы (min-max), \% }\end{array}$ \\
\hline 1 & 8 & $55,9-89$ & $60-100$ \\
1,5 & 5 & $69,4-84,6$ & $60-100$ \\
2 & 32 & $48,0-95,0$ & $60-100$ \\
3,5 & 12 & $23,0-76,0$ & $25-60$ \\
6 & 23 & $3,0-22,7$ & $1-20$ \\
8 & 5 & $2,3-7,3$ & $1-5$ \\
8,5 & 3 & $0-2,3$ & $0-1$ \\
9 & 4 & $0,7-1,3$ & $0-1$ \\
10 & 5 & 0 & $-0,65$ \\
Коэффициент корреляции & & $-0,79$ & 0,42 \\
Коэффициент ковариации & & 0,62 & \\
\hline
\end{tabular}

В условиях низких отрицательных температур $\left(-80{ }^{\circ} \mathrm{C}\right)$ изоляты гриба оставались жизнеспособными в течение 3-10 лет. Число проросших спор у разных изолятов, независимо от срока хранения, составляло 25$79 \%$, а интенсивность поражения растений достигала 25-100\%.

На показатели жизнеспособности изолятов при одинаковых сроках хранения оказывали влияние многие факторы, основными из которых могли быть погрешности при подготовке материала перед закладкой на хранение и нарушения режима хранения технического характера. Тем не менее хранение коллекционных образцов $P$. triticina при низких отрицательных температурах обеспечило достаточно высокую выживаемость в течение 10 лет (табл. 2).

2. Жизнеспособность изолятов Puccinia triticina Eriks. на 2 \% голодном агаре и всходах пшеницы восприимчивого сорта Хакасская в зависимости от длительности хранения в морозильной камере

\begin{tabular}{l|c|c|c|c}
\hline $\begin{array}{l}\text { Год начала } \\
\begin{array}{l}\text { и завершения } \\
\text { опыта }\end{array}\end{array}$ & $\begin{array}{l}\text { Срок хранения, } \\
\text { лет }\end{array}$ & $\begin{array}{l}\text { Число изолятов, } \\
\text { шт. }\end{array}$ & $\begin{array}{l}\text { Доля спор, проросших } \\
\text { на агаре (min-max), \% }\end{array}$ & $\begin{array}{l}\text { Интенсивность пора- } \\
\text { ницы }\end{array}$ \\
\hline $2005-2015$ & 10 & 15 & $34-69$ & $25-80$ \\
$2008-2015$ & 7 & 8 & $34-56$ & $25-60$ \\
$2006-2012$ & 6 & 6 & $45-48$ & 40 \\
$2006-2011$ & 5 & 10 & $25-60$ & $25-80$ \\
$2006-2010$ & 4 & 10 & $45-68$ & $40-80$ \\
$2009-2012$ & 3 & 11 & $50-67$ & $40-80$ \\
$2010-2012$ & 3 & 16 & $35-79$ & $25-100$ \\
$2012-2015$ & 3 & 9 & $53-78$ & $60-100$ \\
Коэффициент корреляции & & $-0,22$ & $-0,41$ \\
Коэффициент ковариации & & 0,05 & 0,17 \\
\hline
\end{tabular}

Хранение изолятов P. triticina при низких отрицательных температурах не сказалось на их вирулентности. Это было подтверждено результатами инокуляции изолятами гриба, снятыми с хранения, растений восприимчивой линии Хакасская и двух моногенных линий сорта Thatcher ( $\operatorname{Lr} 9$ и $\operatorname{Lr} 19)$ (табл. 3). Линии $\operatorname{Lr} 9$ и $\operatorname{Lr} 19$ служили индикаторами виру- 


\section{3. Вирулентность изолятов Puccinia triticina Eriks. до и после хранения при низких отрицательных температурах $\left(-80{ }^{\circ} \mathrm{C}\right)$}

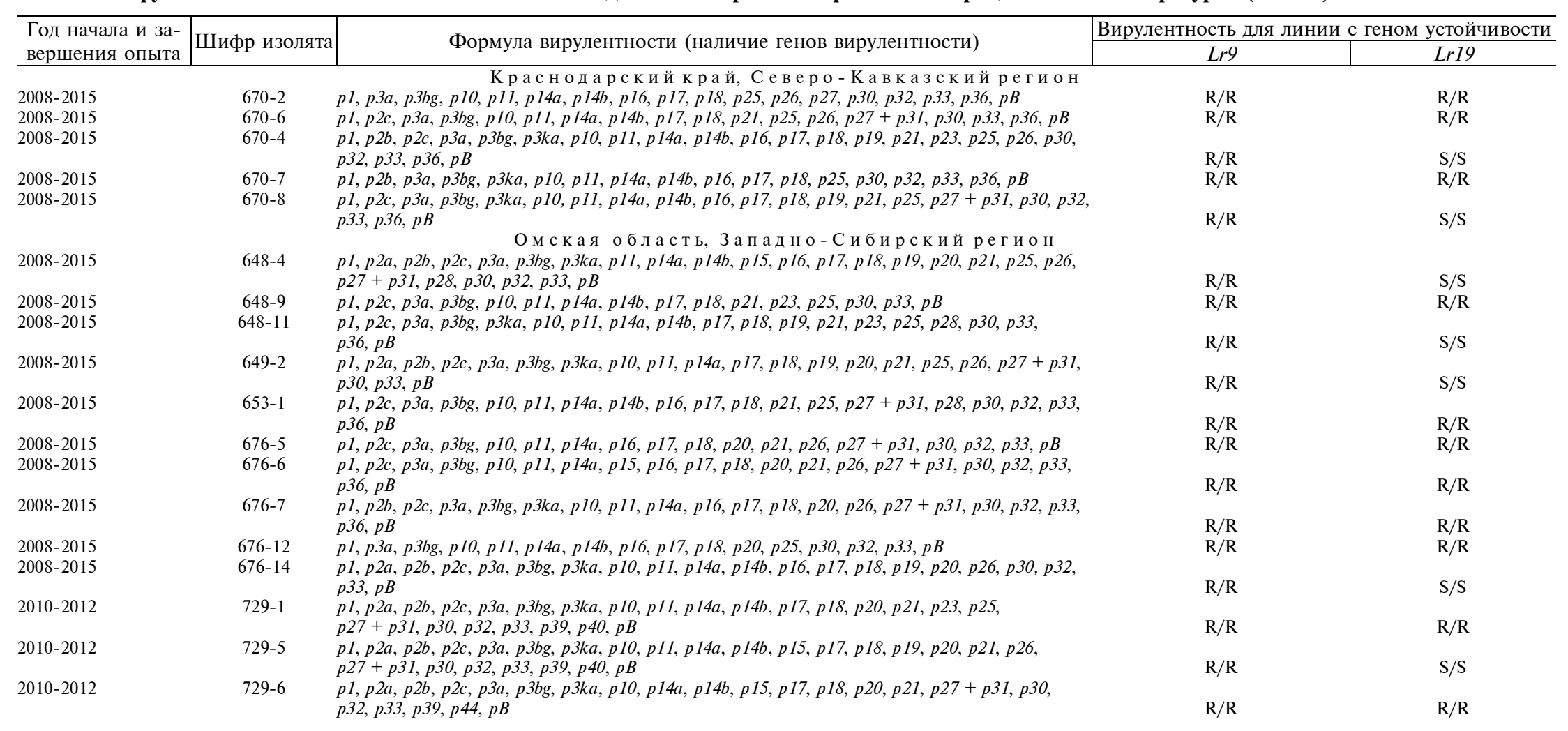


2010-2012

2010-2012

2010-2012

2010-2012

2010-2012

2010-2012

2010-2012

2010-2012

2010-2012

2010-2012

2010-2012

2010-2012

2010-2012

2010-2012

2010-2012

2010-2012

2010-2012 $p 1, p 2 a, p 2 b, p 2 c, p 3 a, p 3 b g, p 3 k a, p 9, p 10, p 11, p 14 a, p 14 b, p 15, p 17, p 18, p 20, p 21, p 23$, $p 27+p 31, p 30, p 32, p 33, p 39, p 40, p B$

$$
\text { Московская область, Центральны й регион }
$$

$p 1, p 2 c, p 3 a, p 3 b g, p 3 k a, p 10, p 14 a, p 14 b, p 17, p 18, p 19, p 21, p 23, p 25, p 30, p 32, p 33, p 39$, $p 40, p B$

p1, p2c, p3a, p3bg, p3ka, p10, p14a, p14b, p16, p17, p18, p21, p23, p25, p27 + p31, p30, p32, $p 33, p 39, p 40, p B$

p1, p2b, p3a, p3bg, p3ka, p10, p14a, p14b, p16, p17, p18, p19, p20, p21, p25, p27 + p31, p30, $p 32, p 33, p 39, p 44, p B$

p1, p2c, p3a, p3bg, p3ka, p10, p11, p14a, p14b, p17, p18, p19, p20, p21, p23, p25, p27+ p31, p30, $p 32, p 33, p 39, p 40, p B$

p1, p2b, p2c, p3a, p3bg, p3ka, p10, p14a, p14b, p17, p18, p19, p20, p21, p23, p25, p27 + p31,

$p 30, p 32, p 33, p 36, p 39, p 40, p B$

$p 27+p 31, p 30, p 32, p 33, p 39, p 40, p B$

$p 1, p 2 c, p 3 a, p 3 b g, p 3 k a, p 10, p 11, p 14 a, p 14 b, p 16, p 17, p 18, p 19, p 21, p 23, p 25, p 27+p 31, p 30$, $p 32, p 33, p 36, p 39, p 40, p 44, p B$ $p 27+p 31, p 30, p 32, p 33, p 36, p 39, p 40, p B$

$p 1, p 2 b, p 2 c, p 3 a, p 3 b g, p 3 k a, p 10, p 14 a, p 14 b, p 15, p 16, p 17, p 18, p 19, p 20, p 21, p 23, p 25$

$p 30, p 32, p 33, p 36, p 39, p 40, p 46, p B$

$p 1, p 2 b, p 2 c, p 3 a, p 3 b g, p 3 k a, p 10, p 11, p 14 a, p 14 b, p 15, p 16, p 17, p 18, p 21, p 23, p 25, p 27+p 31$, $p 30, p 32, p 33, p 36, p 39, p 40, p 44, p 46, p B$ $p 1, p 2 b, p 2 c, p 3 a, p 3 b g, p 3 k a, p 10, p 14 a, p 14 b, p 15, p 16, p 17, p 18, p 19, p 20, p 21, p 23, p 25$,

$p 1, p 2 c, p 3 a, p 3 b g, p 3 k a, p 10, p 11, p 14 a, p 14 b, p 16, p 17, p 18, p 19, p 21, p 23, p 25, p 26$,

Продолжение таблицы 3

$\mathrm{S} / \mathrm{S}$

$\mathrm{R} / \mathrm{R}$

$\mathrm{R} / \mathrm{R}$

$\mathrm{S} / \mathrm{S}$

$\mathrm{R} / \mathrm{R}$

$\mathrm{R} / \mathrm{R}$

$\mathrm{R} / \mathrm{R}$

$\mathrm{S} / \mathrm{S}$ 
лентности изолятов с генами $p 9$ и p19. Изоляты P. triticina (всего 34), собранные в Краснодарском крае, Омской и Московской областях, показали те же реакции на линиях-тестерах, что и при закладке на хранение (см. табл. 3).

Так, сравнение собранных в Западно-Сибирском регионе изолятов 729-5 (с сорта Омская 32), 730-1, 730-2, 730-4, 730-6, 730-11 (с сорта Чернява), 733-3 (с сорта Чернява 13), 732-1 (с сорта Омская 29) не выявило различий по вирулентности для линий $\operatorname{Lr} 9$ и $\operatorname{Lr} 19$ до и после хранения. Образцы уредоспор, отобранные в 2010 году в Московской области с сортов озимой пшеницы Памяти Федина, Московская 39, Мироновская 808, Московская 39 и в 2008 году в Краснодарском крае с сортов Батько, Валерия, Краснодарская 99, Купава, Дельта, Мичиган Амбер, в 2015 году, как и при закладке на хранение, были авирулентными в отношении линии Lr9. В формулах вирулентности изолятов 648-4, 648-11, 649-2 и 676-14 отмечали наличие гена $p 19$. Проверка вирулентности этих изолятов после хранения в течение 7 лет показала идентичные реакции на линиях тестерах.

Несмотря на значительный прогресс в области генетики, биохимии, физиологии и экологии микроорганизмов, механизмы, ответственные за обратимый переход клеток микроорганизмов в анабиотическое состояние, все еще недостаточно изучены. За многолетний период создания коллекций бактерий и грибов накопились общие, но не всегда четкие представления об управлении процессами консервации и восстановления жизнеспособности каждого конкретного организма. Интерес к работам по исследованию структурно-функциональных перестроек клеток микроорганизмов под воздействием факторов консервации-реактивации появился после нахождения живых микробов во льдах Арктики (31). Опыт работы с коллекциями свидетельствует о том, что многие современные методы консервации оказываются относительно эффективными при поддержании лабораторных культур микроорганизмов. Однако консервация при ультранизких температурах с полным сохранением популяций и геномов наиболее результативна, особенно если учесть необычайное физиологическое разнообразие микроорганизмов (19-22).

За период практических испытаний по консервации микроорганизмов были выработаны приемы погружения вегетативных клеток в анабиотическое состояние $(23,24)$, однако работы по выяснению более четких критериев при управлении процессами консервации и восстановления жизнеспособности конкретных микроорганизмов сохраняют актуальность.

Таким образом, нами установлена эффективность использования низких температур $\left(-80^{\circ} \mathrm{C}\right)$ для долгосрочного хранения коллекции изолятов бурой ржавчины пшеницы (от 3 до 10 лет). Низкие температуры даже при хранении материала в течение 10 лет не снижали жизнеспособности и в течение 7 лет не оказывали влияния на вирулентность патогена. Низкие положительные температуры $\left(+4{ }^{\circ} \mathrm{C}\right)$ оказались непригодныдля длительного хранения изолятов Puccinia triticina. Материал в этих условиях сохранялся до 2-3 мес, что не позволяло использовать споры гриба в следующем вегетационном сезоне. Поддержание изолятов $P$. triticina в рабочем состоянии и сохранение их ценных свойств важны не только для популяционной генетики, но и для селекционных исследований.

ФГБНУ Всероссийский НИИ фитопатологии,

143050 Россия, Московская обл., Одинцовский р-н,

пос. Большие Вяземы, ул. Институт, вл. 5,

e-mail: zhemch@mail.ru $₫$, kiseleva@vniif.ru, zhemchuzhina@vniif.ru,

elizarova@vniif.ru
Поступила в редакиию

5 июля 2018 года 


\title{
VIABILITY AND VIRULENCE OF WHEAT LEAF RUST AGENT (Puccinia triticina Eriks.) ISOLATES AFTER LONG TERM PRESERVATION
}

\author{
N.S. Zhemchuzhina, M.I. Kiseleva, A.I. Zhemchuzhina, S.A. Elizarova
}

All-Russian Research Institute of Phytopathology, 5, ul. Institute, pos. Bol'shie Vyazemy, Odintsovskii Region, Moscow Province, 143050 Russia, e-mail zhemch@mail.ru ( $₫$ corresponding author), kiseleva@vniif.ru, zhemchuzhina@vniif.ru, elizarova@vniif.ru

ORCID:

Zhemchuzhina N.S. orcid.org/0000-0001-6374-403X Zhemchuzhina A.I. orcid.org/0000-0002-2060-3306

Kiseleva M.I. orcid.org/0000-0001-7813-3266

The authors declare no conflict of interests

Elizarova S.A. orcid.org/0000-0001-9224-8430

Received July 5, 2018

doi: 10.15389/agrobiology.2019.3.597eng

\section{Abstract}

The State Collection of phytopathogenic microorganisms (ARRIP) accumulates a great number of wheat leaf rust agent (Puccinia triticina Eriks.) isolates, an extremely harmful and epiphytotic pathogen. Annually the collection is replenished with new leaf rust isolates from different populations. Annual estimation of the virulence genes' frequency in isolates makes it possible to track the dynamics of the fungal populations. One of the main tasks of the State collection is to preserve the isolates of the fungus without losing their biological properties to involve these isolates in further laboratory and field experiments. For this purpose, the viability and virulence of $P$. triticina collection isolates was evaluated during 10 -year preservation in a household refrigerator $\left(+4{ }^{\circ} \mathrm{C}\right)$ and in a REVCO freezer $\left(-80{ }^{\circ} \mathrm{C}\right.$, Revco, USA). We used 124 P. triticina isolates collected in 2005, 2006, 2008, 2009, 2010 and 2012 from damaged wheat (Triticum aestivum L.) samples in the Central, North Caucasus and West Siberian regions of the Russian Federation. The isolates differed in virulence and were assigned to 74 phenotypes. The viability of the isolates after storage was determined by spore germination on $2 \%$ water agar plates and by inoculation of susceptible wheat cultivars. Storing of the leaf rust uredospores at low positive temperatures quickly led to a weakening of the viability of the fungus, up to complete destruction. After $1-2$ months at $+4{ }^{\circ} \mathrm{C}$, the isolates had a high germination capacity, from 48 to $95 \%$, which decreased in 6 months to 3.0-22.7 \%. The correlation between the number of germinated spores on $2 \%$ agar-agar and the duration of storage at a low positive temperature was 0.79 . Leaf rust isolates remained viable during storage for 3-10 years under low negative temperatures $\left(-80{ }^{\circ} \mathrm{C}\right)$. The number of germinated spores of different isolates regardless of the preservation period was $25-79 \%$, and the disease intensity reached $25-100 \%$. Many factors influence viability of isolates. These mostly are improper sample processing prior to putting into storage and during reviving from an anabiotic state, or disturbance of storage of technical character. However, storage of $P$. triticina isolates at low negative temperatures ensured a rather high survival rate for 10 years. Checking the virulence of the isolates after 7-year storage with the use of susceptible wheat cultivar and $L r 9$ and $\operatorname{Lr} 19$ lines showed identical indicators before and after the storage. The method of storing spores at $-80{ }^{\circ} \mathrm{C}$ allows rather high rate of preservation without changing fungal viability and virulence.

Keywords: collection of microorganisms, leaf rust, isolate, population, virulence, preservation.

\section{R E F ER E N C ES}

1. Katalog shtammov Gosudarstvennoi kollektsii fitopatogennykh mikroorganizmov i sortov rastenii identifikatorov (differentsiatorov) patogennykh shtammov mikroorganizmov [Catalog of strains of the State collection of phytopathogenic microorganisms and differentiating varieties]. Bol'shie Vyazemy, 2009. Available http://www.vniif.ru/vniif/structure/collection/. No date (in Russ.).

2. Zhemchuzhina N.S., Kiseleva M.I., Abramova S.L., Makarov A.A. Zashchita i karantin rastenii, 2014, 1: 48-50 (in Russ.).

3. Kiseleva M.I., Zhemchuzhina N.S., Kovalenko E.D., Dubovoi V.P., Makarov A.A. Zashchita $i$ karantin rastenii, 2014, 1: 50-52 (in Russ.).

4. Kolmer J.A. Genetics of resistance to wheat leaf rust. Annual Review of Phytopathology, 1996, 34(1): 435-455 (doi: 10.1146/annurev.phyto.34.1.435).

5. Singh R.P., Huerta-Espino J., William H.M. Genetics and breeding for durable resistance to leaf and stripe rusts in wheat. Turk. J. Agric. For., 2005, 29: 121-127.

6. Kovalenko E.D., Zhemchuzhina A.I., Kiseleva M.I., Kolomiets T.M., Shcherbik A.A. Zashchita i karantin rastenii, 2012, 9: 19-22 (in Russ.).

7. Oelke L.M., Kolmer J.A. Characterization of leaf rust resistance in hard red spring wheat cultivars. Plant Disease, 2004, 88(10): 1127-1133 (doi: 10.1094/PDIS.2004.88.10.1127).

8. DadrezaieS., Lababidi S., Nazari K., Goltapeh E., Afshari F., Alo F., Shams-Bakhsh M., Sa- 
faie N. Molecular genetic diversity in Iranian populations of Puccinia triticina, the causal agent of wheat leaf rust. American Journal of Plant Sciences, 2013, 4(7): 1375-1386 (doi: 10.4236/ajps.2013.47168).

9. Kosman E., Ben - Yehuda P., Manisterski, J. Diversity of virulence phenotypes among annual populations of wheat leaf rust in Israel from 1993 to 2008. Plant Pathol., 2014, 63: 563-571 (doi: 10.1111/ppa.12117).

10. Kovalenko E.D., Kolomiets T.M., Kiseleva M.I., Zhemchuzhina A.I., Smirnova L.A., Shcherbik A.A. Metody otsenki $i$ otbora iskhodnogo materiala pri sozdanii sortov pshenitsy ustoichivykh $k$ buroi rzhavchine [Methods for assessing and selecting the source material when creating wheat rust resistant varieties]. Moscow, 2012: 1-93 (in Russ.).

11. Kolmer J.A., Liu J.Q. Simple inheritance of partial leaf rust resistance in two wheat cultivars. Plant Pathology, 2001, 50(5): 546-551 (doi: 10.1046/j.1365-3059.2001.00607.x).

12. Kovalenko E.D., Zhemchuzhina A.I., Kiseleva M.I., Kolomiets T.M., Shcherbik A.A. Zashchita $i$ karantin rastenii, 2012, 9: 19-22 (in Russ.).

13. Liu T.-G., Ge R.-J., Ma Y.-T., Liu B., Gao L., Chen W.-Q. Population genetic structure of Chinese Puccinia triticina races based on multi-locus sequences. Journal of Integrative Agriculture, 2018, 17(8): 1779- 1789 (doi: 10.1016/S2095-3119(18)61923-9).

14. Bolton M.D., Kolmer J.A., Garvin D.F. Wheat leaf rust caused by Puccinia triticina. Molecular Plant Pathology, 2008, 9: 563-575 (doi: 10.1111/j.1364-3703.2008.00487.x).

15. Morgan C.A., Herman N., White P.A., Vesey G. Preservation of micro-organisms by drying; a review. Journal of Microbiological Methods, 2006, 66(2): 183-193 (doi: 10.1016/j.mimet.2006.02.017).

16. Strei W.R., Schmitz R.A. Metagenomics - the key to the uncultured microbes. Current Opinion in Microbiology, 2004, 7(5): 492-498 (doi: 10.1016/j.mib.2004.08.002).

17. Miyamoto-Shinohara Y., Sukenobe J., Imaizumi T., Nakahara T. Survival of freeze-dried bacteria. The Journal of General and Applied Microbiology, 2008, 54(1): 9-24 (doi: 10.2323/jgam.54.9).

18. Pokhilenko V.D., Baranov A.M., Detushev K.V. Izvestiya vysshikh uchebnykh zavedenii. Povolzhskii region. Meditsinskie nauki, 2009, 4(12): 99-121 (in Russ.).

19. Smith D., Onions H.S. The preservation and maintenance of living fungi. CAB International, Wallingford, UK, 1994.

20. Volkov V.Ya. Mikrobiologiya, 1994, 63(1): 5-16 (in Russ.).

21. Kitamoto Y., Suzuki A., Shimada S., Yamanaka K. A new method for the preservation of fungus stock cultures by deep-freezing. Mycoscience, 2002, 43(2): 143-149 (doi: 10.1007/S102670200021).

22. Muldrew K., McGann L.E. Cryobiology - a short course. University of Calgary, Alberta, Canada, 1999.

23. Wolfw J., Bryant G. Cryobiology and anhydrobiology of cells. RMIT University, Melbourn, Australia, 2004.

24. Tedeschi R., De Paoli P. Collection and preservation of frozen microorganisms. In: Methods in Biobanking, Methods in Molecular Biology, Vol. 675. J. Dillner (ed.). Humana Press, Totowa, NJ, 2011: 313-326 (doi: 10.1007/978-1-59745-423-0_18).

25. McIntosh R.A., Dubcovsky J., Rogers W.J., Morris C., Appels R., Xia X.C. Catalogue of gene symbols for wheat, 2013. Available https://wheat.pw.usda.gov/GG2/Triticum/wgc/2013/. No date.

26. Hanzalová A., Bartoš P. Physiologic specialization of wheat leaf rust (Puccinia triticina Eriks.) in the Czech Republic in 2001-2004. Czech J. Genet. Plant Breed., 2006, 42(4): 126-131.

27. Peterson R.F., Campbell A.B., Hannah A.E. A diagrammatic scale for estimating rust intensity of leaves and stem of cereals. Canadian Journal of Research, 1948, 26c(5): 496-500 (doi: 10.1139/cjr48c-033).

28. Kolmer J.A. Physiologic specialization of Puccinia triticina in Canada in 1998. Plant Disease, 2001, 85: 135-138.

29. Uzunova-Doneva T., Donev T. Anabiosis and conservation of microorganisms. Journal of Culture Collections, 2005, 4(1): 17-28.

30. Maintenance of microorganisms. A manual of laboratory methods. B.E. Kirsop, J.J.S. Snell (eds.). Academic Press, London, UK, 1984.

31. McCann C.M., Wade M.J., Gray N.D., Roberts J.A., Hubert C.R.J., Graham D.W. Microbial communities in a high Arctic polar desert landscape. Front. Microbiol., 2016, 7: 419 (doi: 10.3389/fmicb.2016.00419). 